\title{
Taste Preference Differences in Juvenile Delinquency
}

\author{
Ligiana Mihaela Petre ${ }^{1}$, Alina Atalay ${ }^{2}$ \\ ${ }^{I}$ Faculty of Psychology and Educational Science, University of Bucharest, Bucharest, Romania, \\ ligiana.petre@fpse.unibuc.ro \\ ${ }^{2}$ Faculty of Psychology and Educational Science, University of Bucharest, Bucharest, Romania, \\ alinaatalay@yahoo.com
}

\begin{abstract}
Smart food policy models for improving dietary intake recommend tailoring intervention to people's food preference. Food choice plays a major role in the psychological, economic, and social aspects of life by expressing preferences, identities, and cultural meaning. Poor health behavior has been associated with delinquency and antisocial personality features have been associated with taste preferences. The purpose of this study was to identify the taste preferences differences between non-delinquent and delinquent population. PrefQuest (PQ) was used for measuring food preferences. 56 participants were included. The results show a statistically significant difference (18.03) between experimental $(n=21, M=158.13, \mathrm{SD}=30.89)$ and control groups $(\mathrm{n}=35, \mathrm{M}=176.17, \mathrm{SD}=31.19)$ related to sweet taste preferences, $\mathrm{t}(54)=2.10, \mathrm{p}=0.040$, $95 \%$ CI $[.82,35.23]$ and a statistically significant difference (29.30) between experimental $(n=21, M=195.13$, $\mathrm{SD}=50.84)$ and control groups $(\mathrm{n}=35, \mathrm{M}=224.46, \mathrm{SD}=47.78)$ regarding to sweet $\&$ fatty taste preferences, $\mathrm{t}(54)=2.16, \mathrm{p}=0.035,95 \%$ CI $[2.21,56.38]$. There were no statistically significant differences between control and experimental groups related to salty and salty $\&$ fatty taste preferences. The findings could bring a novel insight into the crime prevention strategy based on improving eating behavior, which may contribute to booster the health of the young people with the added benefit of reducing delinquency. Efforts to control delinquency should consider that the adequate emotional reward offered by the food, as an identity and social marker, could be a pathway to psychological rehabilitation in juvenile delinquency.
\end{abstract}

KEYWORDS: delinquency, taste preferences, food choice, health behavior

\section{Introduction}

Juvenile delinquency is a complex, multifactorial problem in today's society, causing considerable financial and societal costs (Spruit, Hoffenaar, van der Put, van Vugt, \& Stams 2018). A metaanalytic review showed that once youth committed a crime, they were more likely to develop a persistent pattern of offending (Assink et al. 2015; Spruit et al. 2018). Moreover, juvenile delinquency often goes with other unwanted developmental outcomes, including educational dropout, unemployment, and health and social problems (Spruit et al., 2018). The risk factors for juvenile offending are individual (e.g. impulsiveness and IQ), familial (e.g. child abuse and family dysfunction), social (e.g. negative peer influences, school commitment problems), and societal (poor housing and low SES) (Murray \& Farrington 2010; Spruit et al. 2018).

Therefore, preventing juvenile delinquency has become an important topic in youth studies. The relationship between diet and antisocial or aggressive behavior has brought substantial interest and contention among psychologists, criminologists, and nutritionists. Research shows a significant negative relationship between good diet and delinquency (Semenza 2018) (2). Poor health behavior may be associated with delinquency because they increase negative health outcomes and illness, which have been associated with delinquency (Semenza 2018) (3). Furthermore, criminality, among other adversities (Yao et al. 2017), has been associated with eating disorders (Coker, Smith, Westphal, Zonana, \& McKee 2014). Rates of committing theft were typically greater in individuals with bulimia nervosa $(\mathrm{BN})$ and the binge-purge subtype of anorexia nervosa (AN) than in individuals with the restrictive subtype of AN (McElroy, Pope, Hudson, Keck, \& White 1991; Vandereycken \& Houdenhove, 1996). Stealing behavior have been related to increased levels of impulsivity, comorbidities, and severity of eating disorders (Blum, Odlaug, Redden, \& Grant 2018; Krahn, Nairn, Gosnell, \& Drewnowski, 1991). Convictions of both theft and other crimes were more prevalent in females exposed to eating disorders than in unexposed females (except other crimes in $\mathrm{AN}$ ) and more prevalent in females exposed to BN than in females exposed to $\mathrm{AN}$. 
It is known that personality traits influence eating styles and food choices and eating styles influence food choices (Petre 2018; Sagioglou \& Greitemeyer 2016). Across time and place, people have used 'foodways' to construct, express, and negotiate their identity (Smoyer 2014, 527). Interactions of food components with human biology and with social and eating context give rise, in some predictable ways, to relatively stable individual food likes or taste preferences (Mela 2006; Petre 2018). Taste-related terms - particularly bitter, spicy, sour, and sweet-are used to characterize behavior and the manner in which people differ from each other. People invoke sweetness metaphors in the interpersonal context (e.g. nicknames for romantic partners "honey," "sugar," "sweetie," and "sweetheart"). Because sweet tastes are especially palatable and pleasant, the word sweet is often used to characterize a kind action, such as a compliment or the granting of a favor or it is used to describe a nice, friendly, and caring person (Meier, Moeller, Riemer-Peltz \& Robinson 2012; Petre 2018). Previous research showed that prison foodways may offer incarcerated women a mechanism for building positive identities: good and healthy (Smoyer 2014, 536). Despite the aforementioned data, the line of research related to the link between eating behavior and delinquency has a lot of space for development. Our study aims to bring more understanding regarding the link between delinquency and a taste preference for food.

\section{Material \& Methods}

The participants were 56 men, 21 young offenders, which were serving sentences for juvenile convictions in Probation Office, and 35 students. Detailed information about socio-demographic characteristics is provided in table 1.

\section{Instruments}

Taste Preferences. The preference for salty, sweet, sweet \& fatty, and salty $\&$ fatty, was assessed with 'PrefQuest' (PQ) (Amélie Deglaire et al., 2012), which measures recalled liking for the four sensations: salty, sweet, fatty and salty, and fatty and sweet. PQ includes four types of items: liking for sweet, fatty-sweet, salty, and fatty-salty; preferences in the level of seasoning by adding salt, sweeteners or fat; preferences for types of dishes in a restaurant menu; overall questions about sweet-, salt-, and fat-related behaviors (A. Deglaire et al. 2015; Amélie Deglaire et al. 2012; Lampuré et al. 2016, 2014). Participants described PQ as short, easy and entertaining. The completion time for PQ items lasted, on average, 23.5 min (Amélie Deglaire et al. 2012). PQ is the first internally validated questionnaire, which proposes a liking score to be calculated based on various types of items, that include liking for foods, preferred seasoning level, and a few items related to dietary behaviors. The factors of each scale had good psychometric properties. Positive correlations between PQ and sensory test measurements in the laboratory have been shown. Therefore, PQ was demonstrated to be valid, repeatable, feasible, and can thus serve as a proxy for sensory test measurements of liking (Lampuré et al. 2014).

\section{Procedure}

The participants were informed about the purpose of the study to explore taste preferences. Each participant was evaluated separately within a psychological setting. The subjects were invited to a psychological assessment of taste preferences. The instructions were presented in the same manner for every participant. A printed version of the PQ was provided to each participant. The subjects were asked to complete the items of PQ according to their general taste preferences irrespective of their current diet or eating behavior. Inclusion criteria included a lifetime absence of psychiatric illness (established through a psychological interview). Exclusion criteria included diagnosis of severe personality disorder or other neurological/medical conditions known to affect mental health. Research Ethics Committee of the University of Bucharest approved the study (IRB no. 03/21.01.2019). The procedure conformed to the College of Psychologists from Romania and the American Psychological Association ethical standards. Participants gave written informed consent, and pseudonyms were used to protect their anonymity. 


\section{Statistical Methods}

PQ was found to have an acceptable normal distribution in the prevailing sample and parametric tests were accordingly used for all analysis. Descriptive statistics were calculated for study variables including frequencies and percentage, and mean, media and standard deviation for age as a continuous variable. An independent t-test was conducted to compare the taste preferences between delinquent and non-delinquent samples. For all statistical analysis, the Statistical Package for Social Sciences (SPSS) was used.

\section{Results and discussions}

\section{Descriptive Statistics}

The participants were 56 subjects, young men between the ages of 19 and 25 . The experimental group consisted of 21 participants and the comparison group of 35 . Table 1 shows the samples' characteristics.

Table 1. Baseline characteristics

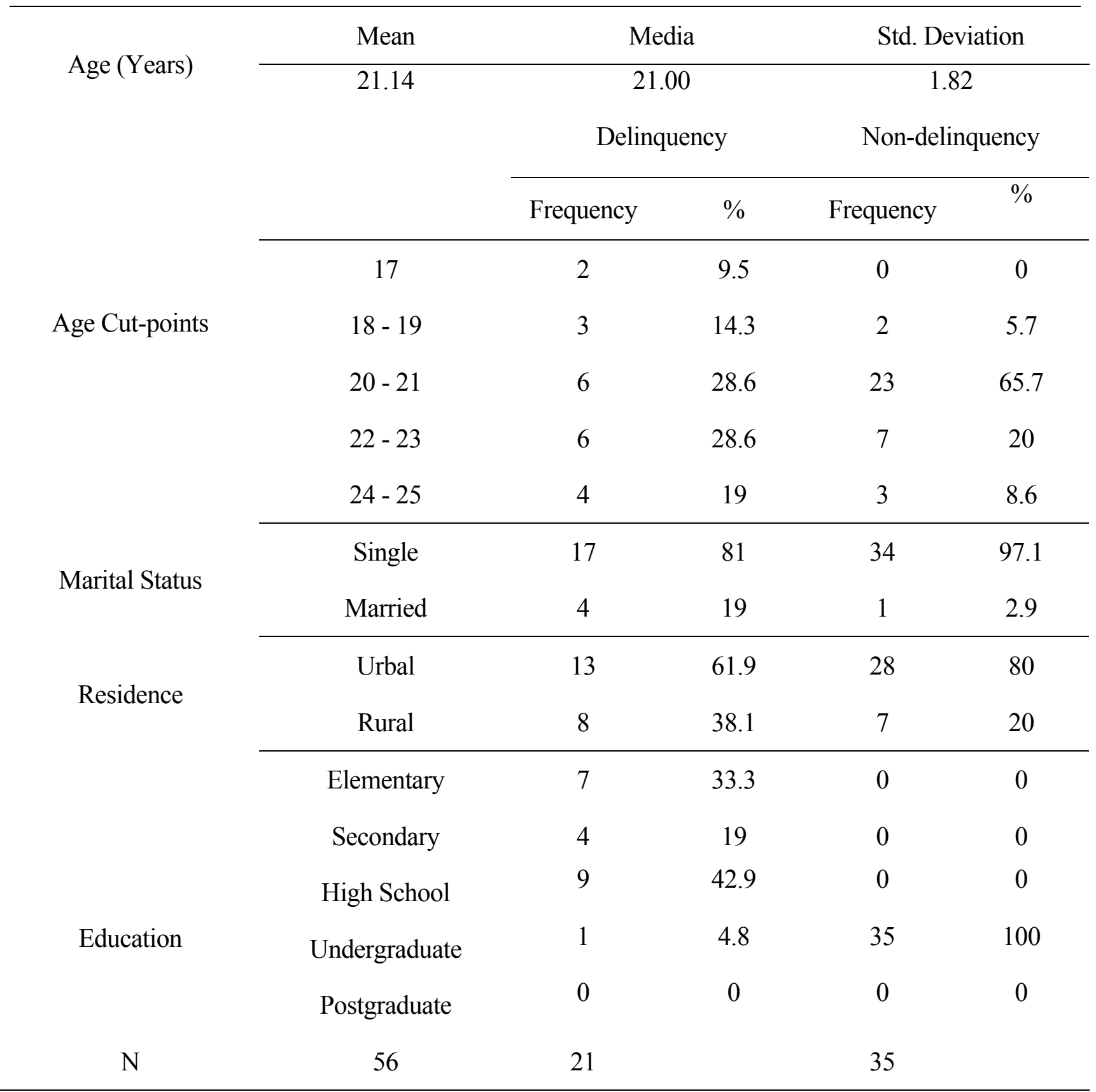


The means of taste preferences between delinquent and non-delinquent samples are shown in figure 1.

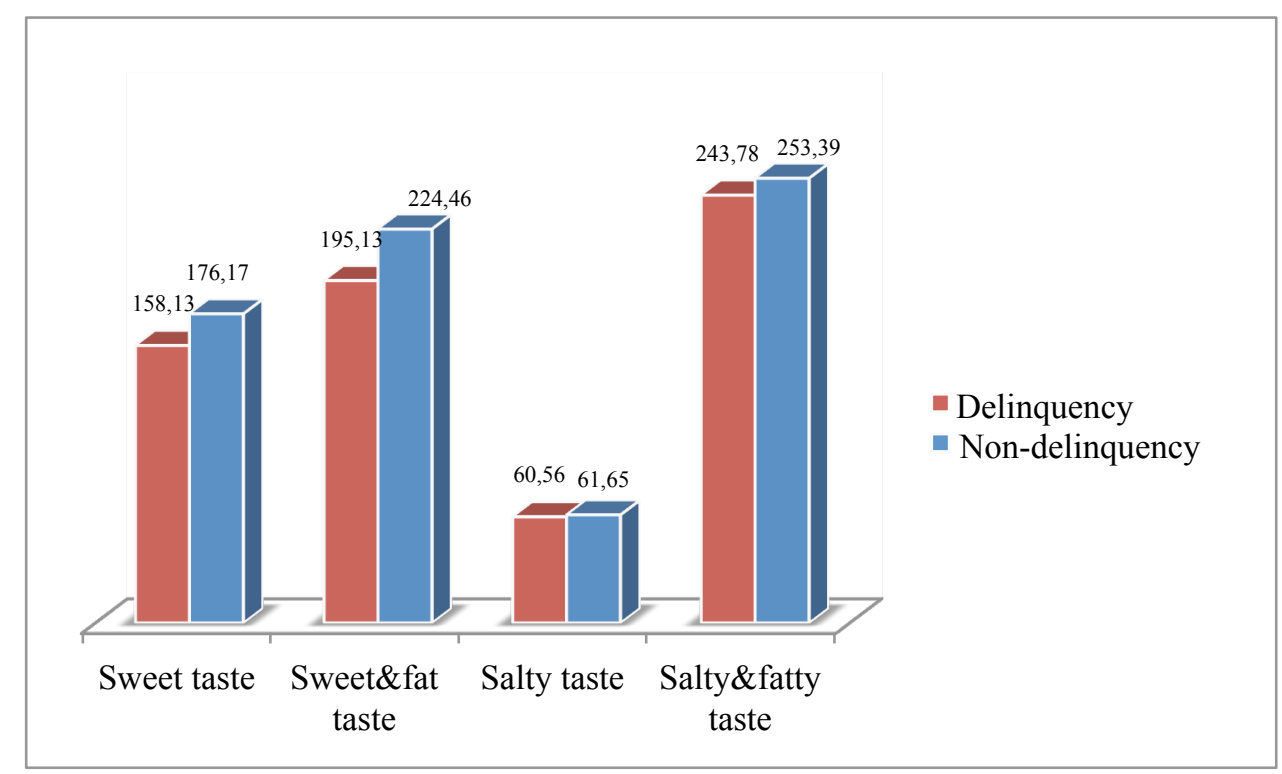

Figure 1. Means of taste preferences

The results show a statistically significant difference (18.03) between experimental $(\mathrm{n}=21$, $\mathrm{M}=158.13, \mathrm{SD}=30.89)$ and control groups $(\mathrm{n}=35, \mathrm{M}=176.17, \mathrm{SD}=31.19)$ related to sweet taste preferences, $\mathrm{t}(54)=2.10, \mathrm{p}=0.040,95 \%$ CI $[.82,35.23]$. There was a statistically significant difference (29.30) between experimental $(\mathrm{n}=21, \mathrm{M}=195.13, \mathrm{SD}=50.84)$ and control groups $(\mathrm{n}=35$, $\mathrm{M}=224.46, \mathrm{SD}=47.78$ ) regarding to sweet $\&$ fatty taste preferences, $\mathrm{t}(54)=2.16, \mathrm{p}=0.035,95 \% \mathrm{CI}$ [2.21, 56.38]. Data suggests no statistically significant differences between control and experimental groups related to salty and salty \& fatty taste preferences (table 2 ).

The future psychological interventions in juvenile delinquency must be focused on the development of smart food policy models for improving dietary intake. Food preferences create a 'voice' that communicates individual and group values. There are differences in taste preferences between young offenders and non-delinquent young men. The interaction's between people's food preferences and the environment in which those preferences are learned, acted upon, and reassessed (Hawkes et al. 2015; Turnwald \& Crum 2019) shapes a personal eating style, which could be reshaped with immediate and long-term effects on health state and emotional balance of the individuals. In order to develop more prosocial behavior and empathic skills, psychologists and nutritionist should target interventions on eating behavior of the young offenders and use taste preferences to construct positive identities and proper emotion regulation strategy, which are also reshaped through eating behavior. The nutritional diets of juvenile offenders must be in agreement with their personality (Petre 2018; Sagioglou \& Greitemeyer 2016), taste preferences and eating behavior.

One of the limits of the present study is the assessment of only four tastes. In addition, the taste preference was measured by recalled liking. Another limitation was the use of a small number of covariates to assess health characteristics of participants. Future studies should take into consideration an experimental study to better control taste preferences, and include bitter, spicy, and umami tastes, or multiple tests to assess recalled liking. 
Table 2

\begin{tabular}{|c|c|c|c|c|c|c|c|c|c|c|}
\hline \multirow{3}{*}{\multicolumn{2}{|c|}{ Taste preferences }} & \multicolumn{4}{|c|}{$\begin{array}{c}\text { Levene's } \\
\text { Test }\end{array}$} & \multicolumn{5}{|c|}{ t-test for Equality of Means } \\
\hline & & \multirow{2}{*}{$\mathrm{F}$} & \multirow{2}{*}{ Sig. } & \multirow{2}{*}{$\mathrm{t}$} & \multirow{2}{*}{ df } & \multirow{2}{*}{$\begin{array}{l}\text { Sig. (2- } \\
\text { tailed) }\end{array}$} & \multirow{2}{*}{$\begin{array}{c}\text { Mean } \\
\text { Difference }\end{array}$} & \multirow{2}{*}{$\begin{array}{l}\text { Std. Error } \\
\text { Difference }\end{array}$} & \multicolumn{2}{|c|}{$\begin{array}{l}95 \% \text { Confidence } \\
\text { Interval of the } \\
\text { Difference }\end{array}$} \\
\hline & & & & & & & & & Lower & Upper \\
\hline \multirow[t]{2}{*}{ Sweet } & $\begin{array}{l}\text { Equal variances } \\
\text { assumed }\end{array}$ & .018 & .893 & 2.101 & 54 & .040 & 18.030 & 8.580 & .828 & 35.232 \\
\hline & $\begin{array}{l}\text { Equal variances not } \\
\text { assumed }\end{array}$ & & & 2.107 & 42.577 & .041 & 18.030 & 8.559 & .764 & 35.296 \\
\hline \multirow[t]{2}{*}{$\begin{array}{l}\text { Sweet \& } \\
\text { fat }\end{array}$} & $\begin{array}{l}\text { Equal variances } \\
\text { assumed }\end{array}$ & .123 & .727 & 2.169 & 54 & .035 & 29.302 & 13.509 & 2.217 & 56.387 \\
\hline & $\begin{array}{l}\text { Equal variances not } \\
\text { assumed }\end{array}$ & & & 2.135 & 40.175 & .039 & 29.302 & 13.725 & 1.567 & 57.037 \\
\hline \multirow[t]{2}{*}{ Salty } & $\begin{array}{l}\text { Equal variances } \\
\text { assumed }\end{array}$ & .553 & .460 & .303 & 54 & .763 & 1.087 & 3.586 & -6.103 & 8.278 \\
\hline & $\begin{array}{l}\text { Equal variances not } \\
\text { assumed }\end{array}$ & & & .314 & 47.093 & .755 & 1.087 & 3.458 & -5.869 & 8.043 \\
\hline \multirow[t]{2}{*}{$\begin{array}{l}\text { Salty \& } \\
\text { fatty }\end{array}$} & $\begin{array}{l}\text { Equal variances } \\
\text { assumed }\end{array}$ & .001 & .980 & .684 & 54 & .497 & 9.608 & 14.044 & -18.548 & 37.764 \\
\hline & $\begin{array}{l}\text { Equal variances not } \\
\text { assumed }\end{array}$ & & & .704 & 45.991 & .485 & 9.608 & 13.655 & -17.879 & 37.095 \\
\hline
\end{tabular}

\section{Conclusions}

The present study sought to address the understudied link between taste preferences and juvenile delinquency in a Romanian sample of youth. The analysis revealed a statistically significant difference between sweet and sweet $\&$ fat taste preferences between the juvenile men offenders and the young man from the comparison group. The findings can contribute to increased understanding of the link between juvenile delinquency and food preferences, and may help build therapeutic and nutritional strategies for promoting healthy eating behaviors and preventing the development of eating disorders associated with delinquency. In addition, the psychological and nutritional rewards of recalled liking could be a pathway to psychosocial rehabilitation of these patients.

\section{References}

Assink, M., van der Put, C. E., Hoeve, M., de Vries, S. L. A., Stams, G. J. J. M., \& Oort, F. J. 2015. "Risk factors for persistent delinquent behavior among juveniles: A meta-analytic review." Clinical Psychology Review 42: 4761. https://doi.org/10.1016/j.cpr.2015.08.002.

Blum, A. W., Odlaug, B. L., Redden, S. A., \& Grant, J. E. 2018. "Stealing behavior and impulsivity in individuals with kleptomania who have been arrested for shoplifting." Comprehensive Psychiatry 80: 186-191. https://doi.org/10.1016/J.COMPPSYCH.2017.10.002.

Coker, K. L., Smith, P. H., Westphal, A., Zonana, H. V., \& McKee, S. A. 2014. "Crime and Psychiatric Disorders Among Youth in the US Population: An Analysis of the National Comorbidity Survey-Adolescent Supplement." Journal of the American Academy of Child \& Adolescent Psychiatry 53(8): 888-898.e2. https://doi.org/10.1016/j.jaac.2014.05.007. 
Deglaire, A., Méjean, C., Castetbon, K., Kesse-Guyot, E., Hercberg, S., \& Schlich, P. 2015. "Associations between weight status and liking scores for sweet, salty and fat according to the gender in adults (The Nutrinet-Santé study)." European Journal of Clinical Nutrition, 69(1): 40-46. https://doi.org/10.1038/ejcn.2014.139.

Deglaire, Amélie, Méjean, C., Castetbon, K., Kesse-Guyot, E., Urbano, C., Hercberg, S., \& Schlich, P. 2012. "Development of a questionnaire to assay recalled liking for salt, sweet and fat." Food Quality and Preference, 23(2): 110-124. https://doi.org/10.1016/j.foodqual.2011.08.006.

Hawkes, C., Smith, T. G., Jewell, J., Wardle, J., Hammond, R. A., Friel, S., ... Kain, J. 2015. "Smart food policies for obesity prevention." The Lancet 385(9985): 2410-2421. https://doi.org/10.1016/S0140-6736(14)61745-1.

Krahn, D. D., Nairn, K., Gosnell, B. A., \& Drewnowski, A. 1991. "Stealing in eating disordered patients." The Journal of Clinical Psychiatry 52(3): 112-115. Retrieved from http://www.ncbi.nlm.nih.gov/pubmed/2005074.

Lampuré, A., Castetbon, K., Deglaire, A., Schlich, P., Péneau, S., Hercberg, S., \& Méjean, C. 2016. "Associations between liking for fat, sweet or salt and obesity risk in French adults: a prospective cohort study." International Journal of Behavioral Nutrition and Physical Activity 13(1): 74. https://doi.org/10.1186/s12966-016-0406-6.

Lampuré, A., Deglaire, A., Schlich, P., Castetbon, K., Péneau, S., Hercberg, S., \& Méjean, C. 2014. "Liking for fat is associated with sociodemographic, psychological, lifestyle and health characteristics." British Journal of Nutrition 112(8): 1353-1363. https://doi.org/10.1017/S0007114514002050.

McElroy, S. L., Pope, H. G., Hudson, J. I., Keck, P. E., \& White, K. L. 1991. "Kleptomania: a report of 20 cases." American Journal of Psychiatry 148(5): 652-657. https://doi.org/10.1176/ajp.148.5.652.

Meier, B. P., Moeller, S. K., Riemer-Peltz, M., \& Robinson, M. D. 2012. "Sweet taste preferences and experiences predict prosocial inferences, personalities, and behaviors." Journal of Personality and Social Psychology 102(1): 163-174. https://doi.org/10.1037/a0025253.

Mela, D. J. 2006. "Eating for pleasure or just wanting to eat? Reconsidering sensory hedonic responses as a driver of obesity." Appetite 47(1): 10-17. https://doi.org/10.1016/j.appet.2006.02.006.

Murray, J., \& Farrington, D. P. 2010. "Risk Factors for Conduct Disorder and Delinquency: Key Findings from Longitudinal Studies." The Canadian Journal of Psychiatry 55(10): 633-642. https://doi.org/10.1177/070674371005501003.

Petre, L. 2018. "Sweetie, No Sweets! Understanding The Association Between Histrionic Personality Style And Taste Preferences." In 5th SGEM International Multidisciplinary Scientific Conferences on SOCIAL SCIENCES and ARTS SGEM2018, Science and Society (Vol. 5). https://doi.org/10.5593/sgemsocial2018/3.2/s11.057.

Sagioglou, C., \& Greitemeyer, T. 2016. "Individual differences in bitter taste preferences are associated with antisocial personality traits." Appetite 96: 299-308. https://doi.org/10.1016/j.appet.2015.09.031.

Semenza, D. C. 2018. "Health Behaviors and Juvenile Delinquency." Crime and Delinquency. https://doi.org/10.1177/0011128717719427.

Smoyer, A. B. 2014. "Good and Healthy: Foodways and Construction of Identity in a Women's Prison." Howard Journal of Criminal Justice 53(5): 525-541. https://doi.org/10.1111/hojo.12097.

Spruit, A., Hoffenaar, P., van der Put, C., van Vugt, E., \& Stams, G. J. (2018). The effect of a sport-based intervention to prevent juvenile delinquency in at-risk adolescents. Children and Youth Services Review, 94, 689-698. https://doi.org/10.1016/J.CHILDYOUTH.2018.09.013.

Turnwald, B. P., \& Crum, A. J. 2019. "Corrigendum to "Smart food policy for healthy food labeling: Leading with taste, not healthiness, to shift consumption and enjoyment of healthy foods" (Preventive Medicine (2019) 119 (7-13), (S0091743518303669), (10.1016/j.ypmed.2018.11.021)). Preventive Medicine. https://doi.org/10.1016/j.ypmed.2019.02.024.

Vandereycken, W., \& Houdenhove, V. Van. 1996. "Stealing behavior in eating disorders: Characteristics and associated psychopathology." Comprehensive Psychiatry 37(5): 316-321. https://doi.org/10.1016/S0010-440X(96)90012-7.

Yao, S., Kuja-Halkola, R., Thornton, L. M., Norring, C., Almqvist, C., D’Onofrio, B. M., ... Larsson, H. 2017. "Risk of being convicted of theft and other crimes in anorexia nervosa and bulimia nervosa: A prospective cohort study in a Swedish female population." International Journal of Eating Disorders 50(9): 1095-1103. https://doi.org/10.1002/eat.22743. 